\title{
Creation of environments and scenarios for learning based on internet habits: a theoretical approach for face-to-face, blended and distance education
}

\section{Creación de ambientes y escenarios para el aprendizaje a partir de los hábitos en internet: un enfoque teórico para la educación presencial, semipresencial y a distancia}

\author{
SIORDIA-MEDINA, Paul Rafael †*, URIBE-OLIVARES, Nadia Sarahi and GONZÁLEZ-BASILIO, \\ Sofía de Jesús
}

Universidad Autónoma de Nayarit

ID $1^{\text {st }}$ Author: Paul Rafael, Siordia-Medina

ID $1^{\text {st }}$ Coauthor: Nadia Sarahi, Uribe-Olivares

ID $2^{\text {nd }}$ Coauthor: Sofía de Jesús, González-Basilio

DOI: $10.35429 / J I T C .2020 .12 .4 .1 .9$

Received July 10, 2020; Accepted December 30, 2020

\begin{abstract}
The creation of virtual learning environments requires extensive pedagogical, methodological and technical knowledge that generates relevant training processes and contributes to the development of student learning. That is why this article presents a proposal for a theoretical framework from which environments and scenarios can be designed and developed based on the Internet habits of students and teachers. Various theoretical and author proposals are integrated that allow understanding the complexity of this great task not only for those who work in the non-school modality, but now for those who have had to make the transition from face-to-face to virtual, which has meant significant changes in their teaching practice, but not only for them, but the students have acquired new habits or reinforced those they already had in order to face the new challenges posed by changes in reality.
\end{abstract}

Environments, Scenarios, Internet habits

\begin{abstract}
Resumen
La creación de ambientes virtuales de aprendizaje requiere de amplios conocimientos pedagógicos, metodológicos y técnicos, que permitan generar procesos formativos pertinentes y que contribuyan al desarrollo de los aprendizajes de las y los estudiantes. Es por ello que en este artículo se presenta una propuesta de marco teórico desde el cual se pueden diseñar y desarrollar estos ambientes y escenarios a partir de los hábitos en internet de estudiantes y docentes. Se integran diversas propuestas teóricas y de autores que permiten comprender la complejidad de esta gran tarea no solo para quienes trabajan en la modalidad no escolar, sino ahora para quienes han tenido que realizar la transición de lo presencial a lo virtual, lo que les ha supuesto cambios significativos en su práctica docente, pero no solo para ellos, sino que los estudiantes han adquirido nuevos hábitos o reforzados los que ya tenían con la finalidad de hacer frente a los nuevos retos plateados por cambios de la realidad.
\end{abstract}

Ambientes, Escenarios, Hábitos en internet

Citation: SIORDIA-MEDINA, Paul Rafael, URIBE-OLIVARES, Nadia Sarahi and GONZÁLEZ-BASILIO, Sofía de Jesús. Creation of environments and scenarios for learning based on internet habits: a theoretical approach for face-to-face, blended and distance education. Journal of Information Technologies and Communications. 2020. 4-13:1-9.

\footnotetext{
* Correspondence to Author (E-mail: paulmedina@uan.edu.mx)

$\dagger$ Researcher contributing as first author.
} 


\section{Introduction}

The implementation of teaching and learning strategies is a constant and permanent exercise to allow students to acquire the expected knowledge or the knowledge established in a study program or learning unit, that is why the implementation, adaptation and updating of them strengthens the chances of this happening with less difficulty. It is here where we must pause a bit to be able to carry out an analysis about all the factors that have influenced our teaching in the educational modality in which we are immersed, whether it is face-to-face, blended or distance, this to try to identify what that has allowed the implemented strategies to have been relatively successful or totally successful, or on the contrary, to have failed. In this analysis it is very likely that we will find something related to the characterization of the student population, the use of some material for learning or technological resource, a permanent monitoring of the process, among other aspects that allow us to establish a base scheme to define a route of adequate work.

Taking as a reference what is stated in the previous paragraph, it is important to point out that one of the ways of incorporating computer technologies into a teaching-learning process can use the aforementioned route, where as a first step an analysis of the population is carried out with the which one is going to interact with, this in order to identify what its characteristics are and therefore its habits on the internet that allow defining an adequate way of working, while establishing permanent monitoring throughout the process to make the necessary modifications.

In this article a theoretical approach will be presented about how to create learning scenarios based on internet habits that can be implemented not only in distance mode, but also in face-to-face and blended learning, this in order to provide an orientation to those teachers who wish to strengthen their way of working with their school groups, as well as to those interested in this type of subject.

\section{Permanent connection to the network}

Everyday life allows us to witness that people are increasingly connected to the internet or using a social network platform. We can clearly show this situation when institutions and companies offer services through applications for cell phones or web pages, as well as information through platforms such as Facebook and WhatsApp that allow almost permanent communication with users, and permanent in some cases. Another much more common example is when we find Facebook accounts or YouTube channels where the users are people of the third and middle age.

In what is expressed in the study on the habits of Internet users in Mexico number 14 [I], it is announced that in 2017 it was recorded that there are 79.1 million Internet users in our country, which represents $66 \%$ of the population according to the data provided by the 2015 intercensal survey (EIC) carried out by the National Institute of Statistics and Geography (INEGI) [II].

Within the same study, it is revealed that the average time that users are connected to the internet is 8 hours 12 minutes (p.9). Which means that a third of the day is dedicated to being on the internet. This is an extremely important figure since if we start from a situation where we take as an example a person who sleeps between 6 and 8 hours on average, we have that half of the remaining 16 hours are used to carry out activities where they use the internet, which can be work, school or leisure. The study also reveals that $89 \%$ of Internet users prefer to navigate through the Smartphone (p. 11), and that $66 \%$ of them are of legal age, being the population between 18 and 44 years old the one that has the most presence when count on $50 \%$ (p.5).

With the data previously presented, what some older adults say is legitimized regarding the fact that people nowadays "spend it all day on their cell phones", and in the same way, the importance of integrating this type of technological resources to the training of people within schools to make use of all that information with which they interact on a daily basis, and thereby enhance some of their skills towards the realization of a life project, the acquisition of new learning and reinforcement of those already obtained, and the diversification of educational scenarios. 
Therefore, it is necessary to identify through which device they access the Internet, what are their browsing habits, as well as their skills in terms of the management of ICTs to establish ad hoc activities and with greater possibilities of achieving learning with their incorporation.

\section{Quality and quantity of information}

The creation and dissemination of content on the internet is very common for those who access a platform for social networks, so it is not uncommon to find texts, images, videos and audios on almost any subject, thus allowing us to be informed in the format that best suits let's consider. Starting from this, it is important to analyze the quality and quantity of information with which we interact on a daily basis to identify those aspects that can become areas of opportunity for the creation of learning scenarios.

There is a very important point to highlight in this new paradigm of collaboration and learning with the support of the internet and new technologies, and that is related to the management of information, since it is very common to find erroneous data that are taken by people as something true by the mere fact of appearing on the internet, mainly on a social network.

An example of what is stated in the previous paragraph is the proliferation of satirical news portals such as El Deforma, El Ruinaversal or El Univerzarro, whose texts have been viralized mainly on Facebook, which are known as "Fake News". Below is an excerpt from a note from El Ruinaversal published on April 13, 2018, which is titled "EPN launches initiative to privatize water" [III]:

Mexico DF. - A clandestine video was released where the president of the republic, Enrique Peña Nieto, declares in front of various public servants his plan to "privatize water", supposedly in order to help Mexicans to have a better service and to save in its consumption.

In the video the president explains that he is "fed up" of being the international mockery, since Mexico is recognized in other nations as "the country where you die if you drink tap water" and stressed that this is not a game since even in several chapters of "South Park" they have mocked this fact (Cortes, 2018, para. 1 and 2).
Examples such as the previous one allow us to highlight the importance of identifying the information that is being worked with in the teaching-learning processes, since sometimes we do not make sure if the sources are reliable, mainly in current affairs, a situation that is not exclusive of students, but also of the teachers in charge, which produces a misinformation that degenerates the learning sought. On the other hand, this type of situation can also be used in some disciplines as a didactic strategy for those subjects related to reading and writing, sociology or the media, to name just a few. Specifically, establishing an analysis of the information to know how it should or should not be integrated into the learning scenarios is something extremely important to achieve the proposed objectives, since it is useless to put it aside since it is It is scattered throughout the different social networks and collections consulted by all of us who inhabit the network.

Another aspect closely linked to the quality of the information is the quantity of it, a situation in which many of us contribute when interacting over the internet, given that the facility we have to generate content allows any user to share information in a specific space or platform. Which has generated that people become very popular thanks to the internet, such is the case of bloggers and youtubers, to mention the best known cases, which periodically generate information that is consumed by us users, however, on the other hand, there are also researchers or academics whose information is shared in spaces such as the Network of Scientific Journals of Latin America and the Caribbean, Spain and Portugal, better known as Redalyc, which facilitates the consultation of articles related to the social sciences, the Arts and Humanities.

Based on these examples, the fact of being able to access various information sources just by typing a word in any search engine is legitimized, which allows us to consult a considerable variety of information, which generates both favorable and unfavorable scenarios. 
Regarding the latter, Capurro (cited in Sebastié Salat, 2008) [IV] thinks that one of the problems of Information Ecology is "the overabundance and redundancy of information" (p.26), something that can complicate the search or analysis of it for those people who are immigrating to the internet or to the same users who have already been part of it for a long time, a situation that generates an area of opportunity from formal education or scenarios for learning to be created, given what to do Adequate or correct use of the spaces where we can consult such information gives us possibilities to diversify the strategies to acquire a particular learning.

For example, activities can be generated for users or students to analyze and discriminate information in relation to a topic, this in order that they can be classified for a more specialized query, a situation that can also be done from the teaching figure, where guidance is given in relation to which sources or collections are adequate to consult. Or in the best of cases, replicate something similar to Redalyc with the same or different format both inside and outside an institution.

\section{Social networks and content generation}

Social networks are popularly associated with platforms such as Facebook, YouTube, TikTok, and Instagram. However, its original concept is far from the use of technology by people. The concept of social network was introduced by John Arundel Barnes (cited in Requena Santos, 1989) [V], and he defines it as follows:

\footnotetext{
"Each person is, as it were, in contact with a number of other people, some of whom are in contact with each other and some of whom are not. I think it convenient to call a social field of this type a network. The image I have is that of a network of points, some of which are connected by lines. The dots in this image will sometimes be people and other groups, and the lines would indicate who interacts with each other" (p. 143).
}

Based on the above, it is extremely important to find and analyze the possible connections between teachers and students in order to determine the points of convergence, and from there define activities aimed at the acquisition of one or more learning.
Therefore, the role of social media is crucial in reorienting educational practices within the classroom when seeking to create those connections.

This type of strategy, that of identifying common aspects between students and teachers to generate connections, works a lot in the classroom, since these aspects are a translator of ideas, as well as a constant and sometimes permanent communication bridge with groups of students. Students, these networks from personal experience, have been maintained to a large extent throughout a school year with the support of some platforms such as Facebook, which has allowed almost permanent communication with students through its function of groups and messaging, which have been of great help in the implementation of various activities. Among the activities carried out in these groups are those of sharing information or generating dynamics in order to obtain significant learning, which is defined by Ausbel (cited in Rodríguez Palmero, 2004) [VI] as:

\begin{abstract}
"The process according to which new knowledge or information is related to the cognitive structure of the learner in a nonarbitrary and substantive non-literal way. This interaction with the cognitive structure does not occur considering it as a whole, but with relevant aspects present in it, which are called subsumers or anchoring ideas" (p.2).
\end{abstract}

Therefore, the use of strategies that promote meaningful learning with the support of social networks and platforms contributes to the identification of convergences between teachers and students, which makes them an ideal tool to be in constant interaction in the learning process. teaching learning.

According to the 14 Study on the habits of Internet users in Mexico carried out by the Internet Mx Association in 2018 (previously mentioned), the use of platforms for social networks is the main activity that Mexicans carry out when we access Internet, the most used being Facebook, WhatsApp and YouTube. They have the characteristic that they can not only be used to consult information or communicate with different people, but also allow their users to generate and share content in different formats that can become known internationally and worldwide, mainly on Facebook and YouTube. 
In Latin American jargon, certain contents that are very popular nationally and internationally have been named "viral" or "viral", among which we find videos, images and audios, which in some cases the author is unknown or author. Many of these contents, apart from being called viral, are also known as "memes", mainly images, and are an important part of current communication between people who inhabit the network.

The generation of content in social networks is not limited to the creation of memes, but also to the grouping of people in relation to a particular topic in forums and Facebook groups, which allow that regardless of the geography where they are located, they can participate in them.

Jenkins (2008) [VII] tells us about how "the collective creation of meanings within popular culture is beginning to change the modes of operation of religion, education, law, politics, advertising and the military world "(P. 15).

And the generation of content on the internet in a collaborative way is a clear example of this because they have established a new dynamic of interaction between citizens, mainly with young people and adolescents, that is why currently it is not strange to see how they are a key factor for political campaigns or social events. A clear example of this within the political sphere in Mexico is what was done by Pedro Kumamoto, who was a deputy in the Jalisco congress, who with the use of social media platforms managed to gain supporters that allowed him to be elected in 2015, a situation that the Spanish newspaper El País relates as follows:

"In every room in the tent there are young people working on laptops. This is how the entire campaign has been: sending WhatsApp messages, responding to tweets, mobilizing the candidate's proposals and videos on Facebook". "We also use Google tools, which are very good, to coordinate volunteers" (El País, 2015) [VIII].

The skills that are used for the generation of content is something that should not be neglected, since from them activities can be carried out that allow innovating the way of working between students and teachers.

\section{New ways of learning}

"Information technologies are at the base of
the changes that have occurred for several
decades in practically all forms of human
learning. A new culture of learning appears
increasingly distant from formal education
systems, from early childhood education to
higher education. Today there are new and
unprecedented possibilities to approach
information, search for it, organize it, contrast
it, represent it, process it, elaborate it and
transform it into knowledge; with new and
powerful forms of dissemination,
communication and collaboration, opening the
way to the search for new approaches and
pedagogical approaches" (Delgado, 2018)
[IX].

\section{Virtual learning}

Vygotsky (1978) [X] affirms that "human learning presupposes a specific social nature and a process by which children access the intellectual life of those around them" (p. 11). These proposed principles can be identified in current learning dynamics, learning generated in virtual environments, where thanks to the interaction of users from all over the world on the network, large-scale collective constructions can be generated that show us a new way of disseminate and build knowledge that allows to rethink the concept of learning through the way in which it can be given.

Regarding the new forms of learning Siemens (2004) [XI] affirms in his work Connectivism: a learning theory for the digital age, that:

Informal learning is a significant aspect of our learning experience. Formal education no longer constitutes the majority of our learning. Learning now occurs in a variety of ways through community practice, personal networks, and through the performance of work tasks" (p. 2).

For their part, Jaussi and Luna (cited in Saso, Aguadé, Gallart and Carol, 2006) [XII] talk about how "learning communities are considered as an egalitarian educational response to achieve an information society for everyone" (p.73). Which are defined by Valls (cited in Saso, Aguadé, Gallart and Carol, 2006) as: 
(...) A project for the social and cultural transformation of an educational center and its environment, to achieve an information society for all people, based on dialogic learning, through participatory education of the community that is specified in all its spaces including the classroom (p.8).

An example of this is Wikipedia, which calls itself "The Free Encyclopedia", in which we can find that in 2020 there are more than 50 million articles in 300 languages [XIII], which are collectively constructed among registered users in it, and bots (computer programs that perform a specific task on the internet) dedicated to permanently reviewing each of the articles. This project strengthens the collaboration networks created independently between people from all over the world for the generation of content, which is accessed by a larger number for consultation.

\section{Connectivism}

The dynamics generated in the network potentiate in a very important way what is established by connectivism, where "the feeding and maintenance of connections is necessary to facilitate continuous learning" (Siemens, 2004, p.6). Which is adjusted to the conditions and sometimes current learning needs of people, mainly that of professionals, where, unlike other times, an almost permanent training has to be maintained due to scientific and technological advances, which they are faster than 20 years ago.

Therefore, identifying the habits that people have on the Internet provides us with elements to define suitable scenarios where the acquisition of learning occurs continuously with the support of new technologies. Scenarios where information is sought to flow permanently in a multidirectional way with the support of all those involved in the learning process.

\section{Virtual environments for learning}

The ways in which it is sought that people learn, assimilate and build knowledge are very diverse. Learning environments are one of the proposals that seek the aforementioned, these are defined by García (cited in Paredes Daza and Sanabria Becerra, 2015) [XIV] as:

\begin{abstract}
A system made up of a diverse set of related and organized elements that make it possible to generate stimulating circumstances for learning. They are based on the planning, design and arrangement of all the elements that promote it and correspond to the context in which the child develops, and to their learning process (p. 151).
\end{abstract}

Its implementation in learning processes must be precisely focused on stimulating learners, which can occur not only with ad hoc physical spaces, as it was manifested in its beginnings, but also in the use of strategies that allow those involved to generate connections to feel part of a group, as well as excited to acquire more information regarding the knowledge addressed. In this sense, the role of the teacher is essential to generate these connections, since they act as a guide and facilitator.

The strengthening of learning environments currently occurs with the integration of new communication-oriented technologies, since thanks to them it is possible to make use of tools that allow strengthening the knowledge acquired by both students and teachers through videos, images , audios, conversations in real time and asynchronously, to name just a few. This integration has allowed the generation of so-called virtual learning environments, which are defined by López Rayón, Escalera, and Ledesma (cited in Martínez de la Cruz et al, 2013) [XV] as:

\begin{abstract}
"The set of interaction environments, synchronous and asynchronous, where, based on a curricular program, the teaching-learning process is carried out, through a learning management system" (p.3).
\end{abstract}

This definition reveals that the key element of virtual environments is the same as traditional environments, that of interaction. Therefore, the activities to be carried out in a curricular space must be permanently focused on ensuring that students constantly interact with each other or with the expected learning through the use of software or applications, as well as practical situations.

\section{Scenarios for learning}

The ease with which people assimilate information about something has a lot to do with the interest of each one of us, since it allows us to carry out the necessary searches to understand everything related to it.

SIORDIA-MEDINA, Paul Rafael, URIBE-OLIVARES, Nadia Sarahi and GONZÁLEZ-BASILIO, Sofía de Jesús. Creation of environments and scenarios for learning based on internet habits: a theoretical approach for face-to-face, blended and distance education. Journal of Information Technologies and Communications. 2020 
The information on the network generates inquiries at various times and periods, which means that we know an event in detail in less than a day. Although, what has been described above does not assure us of learning, if it allows us to identify those tools that can serve us in the future to search for information about another subject, an essential element to take into account when building a learning scenario is involved, and It is because we can take advantage of these search or information management skills to guide certain activities aimed at achieving expected learning.

In this section we will understand learning scenarios as "a set of activities, resources and methods that reflects a learning unit or lesson" (Burgos and Corbalan, 2006, para. 2) [XVI]. Therefore, for its construction it is important to define the activities that allow it to be generated based on the interests of the students, who guide the construction or selection of resources and materials for learning, this without neglecting what is established in the program of studies, which is a guide to the minimum learning that students must acquire.

Based on the above, in the construction of the learning scenarios it is essential to incorporate aspects of the informal environment in formal settings, situations that the student or apprentice performs with great interest in their daily life, and not because it is intended that in the formal study is going to replicate this activity, but with the purpose of identifying how these activities can be used to link them with the knowledge addressed within the curricular space, allowing the generation of learning experiences in which students use everything they know or know to tackle new situations.

Collaborative work can strengthen the generation of these scenarios by allowing students to interact with each other freely to work on a concern or situation. In relation to this, the teacher or facilitator has the task of guiding the "scenarios with flexible curricular and didactic proposals, stimulating inquiry and autonomy" (Salinas, De Benito and Lizana, 2014, p.151) [XVII].
In this sense, the construction of scenarios for learning in virtual environments can use elements proposed in the instructional design, which will allow a structure to be based on. Next, the ASSURE model is detailed, where the characteristics that contribute to the generation of the scenarios are highlighted.

For Heinich (cited in Benítez Lima, 2010) [XVIII]: the ASSURE model is oriented to the classroom and is based on the approach of Robert Gagné (1985); It has its theoretical roots in behaviorism due to the emphasis on the achievement of learning objectives, however, constructivist traits are identified by worrying about the active and committed participation of the student (p. 7).

The ASSURE model consists of six procedures:

- The analysis procedure consists of identifying the socioeconomic and cultural aspects, learning styles, school trajectory and the expectations of the students, just to mention some elements that influence the behavior of the students (Benítez Lima, 2010).

- After carrying out the analysis of the student population, it is necessary to establish learning objectives so that students have knowledge of the learning that they will be able to acquire in a moment (Benítez Lima, 2010).

- The selection of strategies, technologies, means and materials allows teachers to decide which tools are to be used within the course to achieve the expected learning (Benítez Lima, 2010).

- $\quad$ Organizing the learning scenarios implies defining the activities that will be carried out during all the sessions, which are aimed at enabling students to acquire the expected learning (Benítez Lima, 2010).

- The participation of students is a very important element for the model, since it is sought that they interact constantly so that they exchange information in an almost permanent way, which contributes to the desired learning being less complicated to acquire (Benítez Lima, 2010). 
Evaluation and review of the implementation and learning outcomes. In it, an assessment of the learning achieved by the students is carried out; the performance of the teacher and the total course is evaluated (Benítez Lima, 2010).

The procedures established in the previous model, mainly that of the analysis of the characteristics of the students, the organization of the scenarios for learning, and the participation of the students, will allow to guide the construction of the scenarios in an appropriate way by contemplating key elements such as student interests are.

\section{Conclusion}

The creation of environments and scenarios for learning contributes to redefining the way in which one works both in conventional and nonconventional modes of education, this by defining strategies that are built from the identification of Internet habits that students and students have. teachers, which is a success, since it starts from what they do on a daily basis on the internet, as well as from the way they access it, and not from a scheme alien to them that runs the risk of being rejected in their totality to be imposed. As a clear example of this that is mentioned, there are the multiple situations presented in the current pandemic generated by the coronavirus, where the rejection of the proposal of online and virtual classes is given by both teachers and students, since apart from the limited access or null to the Internet, the conditions of interaction between students and teachers were not taken into account, they were only "forced" to adopt a scheme that little by little has been fortunately assimilated and adapted to the conditions of each context, it is important clarify that it is understood that the Federal Government's proposal is perfectible, and that given the circumstances it is understandable that this was not fully accepted at first, what is rescued here is what was mentioned previously, which after a while, each institution and teachers, were adapting it according to their work characteristics and those of their group, something that comes to legitimize what is addressed in this document respect cto the creation of environments and scenarios for learning.

\section{References}

[I]. Asociación de Internet.mx (2018). 14 Estudio sobre los hábitos de los usuarios de internet en México 2018. https://irpcdn.multiscreensite.com/81280eda/files/ uploaded/Estudio $\% 20 \mathrm{de} \% 20 \mathrm{los} \% 20 \mathrm{Ha}$ $\%$ CC $\% 81$ bitos\%20de\%20los\%20Usuari os $\% 20 \mathrm{de} \% 20$ Internet $\% 20 \mathrm{en} \% 20 \mathrm{Me} \% \mathrm{C}$ C\%81xico\%20AIMX\%202018_E6Cma xlbT4ObjDOPahbT.pdf

[II]. INEGI. Censos de y Conteos de Población y Vivienda. Población total de México. Recuperado de: http://www.beta.inegi.org.mx/temas/estr uctura/

[III]. El Ruinaversal. EPN Lanza iniciativa para privatizar el agua. Recuperado de: http://www.elruinaversal.com/2018/04/1 3/epn-lanza-iniciativa-para-privatizar-elagua/

[IV]. Sebastiá Salat M (2008). La ecología de la información: un nuevo paradigma de la infoesfera. Recuperado de http://www.pliegosdeyuste.eu/n78pliego s/pdf/2008-7-8-23-34.pdf

[V]. Requena Santos F. (1989). El concepto de red social. Recuperado de: http://www.reis.cis.es/REIS/PDF/REIS_ 048_08.pdf

[VI]. Rodríguez Palmero M. (2004). La teoría del aprendizaje significativo. Recuperado de: http://cmc.ihmc.us/papers/cmc2004290.pdf

[VII]. Jenkins H. (2008). Convergence Culture: La cultura de las convergencias en los medios de comunicación. Barcelona, España: PAIDÓS.

[VIII].Corona S. (2015). Así derrotó Kumamoto a los grandes partidos mexicanos. El País. Recuperado de https://elpais.com/internacional/2015/06 /10/actualidad/1433965144_500663.htm 1 
[IX]. Delgado García L. (2018). Nuevas formas de aprender. Recuperado de https://www.milenio.com/opinion/luisrey-delgado-garcia/parareflexionar/nuevas-formas-de-aprender

[X].L.S. Vygotsky L.S. (1978). El desarrollo de los procesos psicológicos superiores. Barcelona, España: Crítica.

[XI].Siemens G. (2004). Conectivismo: Una teoría de aprendizaje para la era digital. Recuperado de http://clasicas.filos.unam.mx/files/2014/ 03/Conectivismo.pdf

[XII].Saso Elboj C., Puigdellívol Aguadé I., Soler Gallart M., y Valls Carol R. (2006). Comunidades de aprendizaje. Transformar la educación. España: GRAO

[XIII].Wikipedia. Recuperado de https://es.wikipedia.org/wiki/Wikipedia

[XIV].Paredes Daza J, y Sanabria Becerra W. (2015). Ambientes de aprendizaje o ambientes educativos: Una reflexión ineludible. Recuperado de: http://www.revistas.ucm.edu.co/ojs/inde x.php/revista/article/download/39/39

[XV].Martínez de la Cruz N., Galindo González R., y Galindo González L. (2013). Entornos virtuales de aprendizaje abiertos; y sus aportes a la educación. XXI Encuentro Internacional de Educación a Distancia. Educación virtual en los cinco continentes. Recuperado de: http://www.udgvirtual.udg.mx/encuentr o/encuentro/anteriores/xxi/ponencias/80 -127-1-RV.pdf

[XVI].Burgos D. y Corbalan G. (2006). Modelado y uso de escenarios de aprendizaje en entornos b-learning desde la práctica educativa. Recuperado de: https://www.researchgate.net/publicatio n/240484630_Modelado_y_uso_de_esc enarios_de_aprendizaje_en_entornos_blearning_desde_la_practica_educativa
[XVII].Salinas J., De Benito B. y Lizana A. (2014). Competencias docentes para los nuevos escenarios de aprendizaje. Recuperado de: https://www.redalyc.org/articulo.oa?id= 27431190010

[XVIII].Benítez, María. (2010). El modelo de diseño instruccional ASSURE aplicado a la educación a distancia. Tlatemoani. Recuperado de: https://www.researchgate.net/publicatio n/46562749_EL_MODELO_DE_DISE NO_INSTRUCCIONAL_ASSURE_AP LICADO_A_LA_EDUCACION_A_DI STANCIA 